\title{
UIP, the carry trade and Minsky's Financial Instability Hypothesis in the CEE and CIS
}

\author{
Rob Hayward and Prof. Jens Hölscher
}

September 3, 2013

\begin{abstract}
An investigation of a sample of potential carry-trades for a number of countries in Central and Eastern Europe and the Commonwealth of Independent States exhibits similar characteristics to the build up of macroeconomic financial instability as presented by Hyman Minsky. The trade is generally profitable relative to funding costs and measured against a stock index investment benchmark. As with the Financial Instability Hypothesis, when conditions in the international financial system are calm, returns for the carry trade are highest and subject to less risk than the occasions when international uncertainty, risk aversion or political and economic worries about the investment currency are high. The nature of the risk that is taken when investing in the carry-trade strategy helps to explain the frequent deviations from uncovered interest parities that have been found in the literature and adds to the understanding of the nature of the risk associated with financial instability.
\end{abstract}




\section{Introduction}

The carry trade is the attempt to take advantage of deviations from uncovered interest parity (UIP). UIP is one of the fundamental theories of international financial economics. UIP asserts that, given the free flow of capital, the expected change in an exchange rate over a specific period should be equal to the interest rate differential for the two currencies for the same period. If this is not the case, there is an opportunity to make an abnormal return, using the carry trade, by borrowing one currency and investing the proceeds in the other. A large body of evidence and the activity of speculators, who it appears trade on information, suggests that UIP does not hold.

In the carry trade, speculators are betting that the depreciation of the investment currency against the funding currency will be less than the interest rate differential. There are two main explanations for why the carry trade is so popular ${ }^{1}$ : there may be an inefficiency in the markets processing of information that will allow abnormal returns to be generated by this investment approach; there may no inefficiency and the returns that are achieved may be a compensation for taking an unusual type of risk. It has been shown that speculation is unlikely to be completely uninformed. This chapter assesses the latter with an investigation of the nature of carry trade returns. These returns are found to be leptokurtic (or fat-tailed), negatively skewed, serially correlated in many cases, affected by the type of currency regime and sen-

\footnotetext{
${ }^{1}$ The discussion of the carry trade and its size or significance rises and falls. It has often focused on specific countries such as Turkey, Iceland, the Czech Republic where interest rates are unusually high and on funding currencies like the US dollar, the Swiss Franc, Euro and Japanese Yen where interest rates are relatively low and a developed banking system is ready to provide funding for investors searching for higher yields. However, there are no figures on the size of the activity.
} 
sitive to changes in international risk aversion. The evidence suggests that the returns to the carry trade are not abnormal but a return for taking crash risk that is characterised by unpredictable large losses that increase with the length of the period running up to the crash.

In this way, the carry trade can be seen as being a micro version of Minsky's Financial Instability Hypothrsis (FIH) While Minsky presents a story where there is a gradual build up of speculative borrowing, increased fragility then a crash, carry trade positions are likely to be built while conditions are calm; the establishment of carry trade positions appear to generate abnormal returns as the purchase of the investment currency will tend to cause it to appreciate rather than depreciate; the carry trade itself will start to generate crash risk as the appreciation of the investment currency takes it further away from equilibrium which can increase the risk of crash and ensure that any crash that happens is deeper and more damaging than would otherwise be the case. In this way the carry trade receives a compensation for taking crash risk. However, the carry trade also causes an increase in the amount of crash risk.

This paper assesses carry trades in Europe. There are a number of conditions that make Europe a very fertile ground for this activity: there have been periods when there have been relatively large interest rate differentials between some countries; there are a number of fixed exchange rate regimes; there is a divergence between very highly developed financial systems in the core and less developed systems to the periphery. These are all features that encourage the establishment of carry trade positions. However, it is very likely that the results established here would be applicable to other parts of 
the world.

Europe is also a good place to start with some analysis of speculative activity in the foreign exchange market because there is a rich history of speculative activity in European foreign exchanges. From the successive devaluations of sterling under the Bretton Woods system through to the crises of the Exchange Rate Mechanism (ERM) into some of the monetary problems that CEE countries have faced when they have tried to stabilise their exchange rates, European nations have sought to limit effects of speculation on their economies. Most recently a version of the carry trade has caused some problems in Europe as it has led to led to large capital flows into those countries with relatively high rates of return within the Euro area (like Greece and Spain).

\section{Literature}

UIP takes the form,

$$
\frac{E\left[S_{t+j}\right]-S_{t}}{S_{t}}=\frac{\left(i_{t, j}-i_{t, j}^{*}\right)}{\left(1+i_{t, j}^{*}\right)}
$$

Where $E\left[S_{t+j}\right]$ the expected value of the exchange rate $(S)$, defined as overseas units of domestic currency, at time $t$ for $j$ periods ahead, $i_{t, j}$ is the

domestic interest rate at time $t$ for $j$ periods ahead and $i_{t, J}^{*}$ is the equivalent for the foreign currency denominated interest rate.

There is no carry trade if this holds as the gain from borrowing a lower interest rate currency and depositing in a higher yielding unit will be ex- 
pected to be balanced by a capital loss on the depreciation of the investment currency against the funding unit. However, the evidence from Froot and Thaler (Froot, 1990) and others suggests that UIP does not hold on average. Estimating the $\beta_{1}$ from Equation 2

$$
\Delta s_{t+j}=\beta_{0}+\beta_{1} f_{t+j}+\varepsilon
$$

finds that the value is usually much lower than the value of one that would be implied by UIP. Indeed, the fact that the carry trade exists shows that there are investors who believe that they can identify the times when UIP will not hold. As UIP is based on notions of rationality and arbitrage and a key component of international financial theory, there has been a tremendous effort to understand more about this apparent failure. (Engel, 1996) and (Roll and Yan, 2000) suggest that it is the lack of stationarity in the series that causes estimation problems; (Bansal and Dahlquist, 1999) argue that this is more a problem for developed rather than developing nations; (Chinn and Meredith, 2004) report that this is more of a short-term issue than one for the long horizon as they carry out tests using 10 year bond yields.

\subsection{Risk Premium}

If the assumption that investors are risk neutral or indifferent to risk is abandoned in favour of risk aversion there will be a risk premium to compensate investors for taking risk. The interest differential will be equal to the expected change in the exchange rate plus an additional premium for taking the risk of an adverse outcome. In that case the negative estimate for $\beta$ could 
mean that investors required additional return for holding foreign currency assets. As such, it is possible to augment Equation 2 with an additional term that would account for the risk premium.

$$
E\left[\Delta s_{t+j}\right]=\beta_{0}+\beta_{1} f_{t+j}+\beta_{2} r p_{t}+\varepsilon
$$

This means that the expected change in the exchange rate is equal to the forward discount or the interest rate differential plus a risk premium. If the forward rate $f_{t+J}$ is five percent below the spot rate $s_{t+j}$, because the interest rate differential $\left(i_{t+j}-i_{t+j}^{*}\right)$ is five percent in favour of the overseas currency, the expected appreciation of the domestic currency $E\left[\Delta s_{t+J}\right]$ should be five percent and $\beta_{1}$ and $\beta_{2}$ should therefore sum to one otherwise there is a breakdown of UIP and an opportunity for the carry trade. If $\beta_{1}$ is below zero, $\beta_{2}$ must be equally positive, indicating that an additional return is required for taking the risk of making an overseas investment. This seems entirely reasonable until it becomes clear that there are many cases where domestic interest rates are higher than those abroad and the carry trade will involve borrowing overseas for a domestic investment. UIP does not hold in these cases and now there is a risk premium for holding domestic assets and the argument breaks down. There may, of course, just be a return for taking risk, but the return to the carry trade appears excessive compared to the risk premium in other financial assets.

Bilson addresses this and other factors that may drive a wedge between the forward rate and the expected rate by considering speculative efficiency which is efficiency once risk premia, transaction costs and information costs 
have been been accounted for. He finds the optimal investment strategy and tests it under a variety of specifications, including out of sample, finding that there are no other factors that can add to the forecasting ability of the forward rate (Blison, 1981).

However, as the risk premium is not observed, the model is not identified unless some additional restrictions are imposed.

$$
r p_{t}=f d_{t}+\Delta s_{t+j}^{e}
$$

By using surveys of expectations, from the Economist Financial Report for the period June 1981 to August 1988, Froot is able to isolate the effect of the risk premium by using the survey to estimate $\Delta s_{t+j}^{e}$. The survey measures reveal that abnormal returns are expected on foreign currency deposits when US interest rates are low and these expectations do not usually include a risk premium. Where there does appear to be a premium it is very small. However, as discussed in Chapter 3 Footbote, survey evidence is not particularly reliable or comprehensive and the analysis of the risk premium as an explanation of the forward bias puzzle has continued.

Indeed, Froot also shows that short rates consistently predict excess returns on a variety of assets. For foreign exchange, stock, bond and commodity markets, a one percentage annualised increase in the short term interest rate is associated with about a three percentage point reduction in annualised excess returns (Froot, 1990). There could also be a liquidity issue that is not formally addressed by Foot. If low interest rates are symptomatic of money creation in the banking system from lending that is being used to pur- 
chase assets, this can lead to lead to short run appreciation of assets values. This would be consistent with the Minsky-type behaviour where informedspeculators push asset prices beyond levels associated with intrinsic value, raising the risk of a violent reversal once the liquidity spigot is turned off.

\subsection{Expectations}

There are two related questions that need to be addressed: are expectations about future exchange rates formed in a fashion that can be considered ratio$n a l$; and, what is the information set on which these expectations are formed. In the analysis conducted thus far, expectations are assumed to be rational in the sense of Muth (Muth, 1961), meaning that economic agents understand the model that describes the system and that therefore there are no systematic expectational mistakes (see Section for further discussion on rational expectations). This means that, as described above, if UIP describes the relationship between interest rates and the exchange rate, economic agents form their expectations by this rule.

The so-called peso problem came from an analysis of the Mexican peso and implies that when there are expectations about a future, discrete change in fundamental value, rational forecast errors may be consistently different from zero. For example, if there is considered to be a $5 \%$ chance of a $50 \%$ devaluation of a fixed exchange rate, the expected depreciation of $2.5 \%$ will never actually be seen. This raises a series of questions about how far economic agents can be expected to form subjective probability estimates of future events that match the objective probabilities as suggested by (Muth, 
1961, p. 316). There is a lot of evidence to suggest that this is not possible. See Section for a discussion of rational expectations and Section for more detail of behavioural theories of decision-making that indicate that there is particular difficulty with the assessment or estimation of the probability of events that are extremely unlikely (Kahneman and Tversky, 1979).

It is also possible that expectation could be formed on wider information set than the sample of exchange rate returns that were available to researchers. If market participants fear a large, future depreciation of an exchange rate (say the Mexican peso, which is the example most initially used to explain the Peso Problem), the fact that this is a rare or even unique event means that these expectations may not be recovered from the historic sample of the Mexican peso. Rogoff looked at the Mexican peso futures from June 1974 to June 1976 and found evidence contrary to the implications of market efficiency but explained by the market's persistent belief that the Mexican peso would be devalued. The peso was devalued in August 1976 and again in December 1994 (Rogoff, 1980), (Lewis, 2008). Therefore, expectations were proved right even though pre-devaluation research would find a problem.

This may lead back to risk. An explanation that is partially explored by Froot and Thaler is that assessing risk by the first two moments of a distribution is inadequate in a situation where returns are not expected to be normally distributed. There are steady returns from a long Mexican peso position funded by US dollars, but also large and uncertain risks that are very difficult to quantify. Small risk of extreme inflation and large depreciation of the peso would not be balanced by any similar possibility of an appreciation of the Mexican unit and therefore the distribution of inflation expectations 
is very likely to show a large negative skew (Froot and Thaler, 1990, p. 186).

\subsection{Crash risk}

There are a number of recent studies that have assessed the skewed nature

of the returns that are associated with the carry trade. For example, Brunnermeier and Pedersen develop a general model of what they call crash risk which is due to the sudden unwinding of carry trade. The crash happens when risk appetite and funding liquidity decreases. They use exchange rates for the US dollar against eight major currencies for the period 1986 to 2006 and the three month interest rate to assess the returns for an investment in foreign currency financed by domestic (US) currency.

$$
z_{t+1} \equiv\left(i^{*}-i\right)-\Delta s_{t+1}
$$

where $z_{t+1}$ is the return in excess of the prediction of UIP as $i^{*}$ is the $\log$ of the overseas three month interest rate and $i$ is the domestic three month interest rate and $\Delta s_{s+1}$ is the change in the log of the exchange rate measured as foreign currency per US dollar (Brunnermeier et al., 2008, pp. 8-9). They find that carry trades have large Sharpe Ratios, negative skewness and positive excess kurtosis. However, as the Sharpe Ratio assumes a symmetric distribution of returns, there are some clear weaknesses in this method.

Brunnermeier shows how this crash risk can be increased by the interaction of institutional features like illiquidity, margin calls and the evaporation of speculator funding. When conditions deteriorate, investors seek to exit the carry position, liquidity declines, banks become more cautious about fund- 
ing speculative positions and an increase in margin requirements, together with a reduction in funding lead to spirals of selling and exaggerated price movements (Brunnermeier and Pedersen, 2009).

Gabrisch and Orlowski carry out an investigation of equity markets, money market rates and exchange rates in some CEE countries using a mean version of the general auto-regressive conditional hetroscedasticity model with a generalised error distribution (GARCH-M-GED) to assess the nature of the disturbances in these time series. Inflation targeting countries of Czech Republic, Poland, Hungary and Romania are assessed with a sample from January 32000 to August 7 2009. The study finds that there is evidence of leptokurtic disturbance for each of these financial variables with the GED parameter significantly below the level of two that would be associated with a normal distribution. They argue that this type of behaviour of financial assets makes the operation of a Taylor Rule for monetary policy inoperable. It is clear that fat-tailed, negative-skewed distributions are a common feature of CEE financial markets. Indeed, it appears that foreign exchange shocks, such as the effects of the carry trade, translate across other financial markets (Gabrisch and Orlowski, 2011).

Spronk, Vershoor and Zeinkel use a hetrogenous agent model with carry traders in addition to fundamental and chartist traders. This is an augmentation of the model of fundamental and chartist traders that is presented by (Frankel and Froot, 1990) where fundamental traders expect a return to fundamental value and chartists expect a continuation of the trend. Traders adjust their strategy towards those that are most successful. The model is able to replicate the heavy tails, excess volatility and volatility clustering 
that is evident in foreign exchange rates. Another interesting feature of this model that suggests a link with Minsky's FIH is the negative relationship between market volatility and carry trade activity (Spronk et al., 2013). The carry trade is built while conditions are calm.

Variants of the carry trade are a key component of capital flow in emerging economies with fixed exchange rates. Korinek assesses the welfare implications of capital flows from the stance of externalities. These externalities emerge due to the failure of agents to account for the systemic risk that is created by capital inflow. Korniek says that emerging markets may appear to be integrated into international markets but this integration is contingent upon financial constraints not being binding. Private agents fail to internalise the endogenous nature of the access to international financial markets. This risk is a function of the build up of foreign currency debt and the amplified potential for a feedback loop to exacerbate capital outflow, exchange rate depreciation and the reduction in the overseas value of domestic collateral and ability to service debt. In other words, there are carry trade participants that fail to fully appreciate the crash risk that they are taking.

Korniek proposes a tax to internalise these external risks and suggest different levels of tax for different types of capital inflow based on the probability of future capital outflow. This puts the largest tax on foreign currency debt and the smallest on foreign direct investment flow. Korniek argues that the risk of capital outflow changes over time with the greatest risk after a period of high capital inflow and the lowest risk after a period of re-balancing (Korinek, 2011)

In order to try to quantify the value of this crash risk, Jurek has tried 
to quantify the expectations of something like a catastrophic risk that may be apparent in UIP by looking at the price of options that could be used to hedge potential crash in the exchange rate. He asserts that the common finding that carry trades generate excess returns is misleading because these returns are a compensation for risk. Though he finds that G10 carry trades for the 1990-2008 period generate Sharpe Ratios that are twice the level of the S\&P 500 equity returns, Jurek estimates that these generally disappear once the cost of option hedging of crash risk is included (Jurek, 2007). This is consistent with the notion that any returns to the carry trade (see Equation 5) are a compensation for taking crash risk rather than abnormal or excess return.

\subsection{European financial markets}

There are two main types of speculative activity associated with the carry trade that have been found in the European foreign exchange markets. The first is that conducted by professional carry trade investors, taking advantage of the break-down in UIP and apparently well aware of the risk that they are taking; the second are regular households that are attracted to the trade by the incentive of a low level for foreign currency interest rates. Domestic households are a significant, less well informed component, and, in most cases, less able to absorb the sort of losses that can occur in extreme periods. The European Bank for Reconstruction and Development (EBRD) Transition Report for 2010 called Recovery and Reform puts an emphasis on the need to develop local currency capital markets as a critical part of the 
post-crisis reform agenda as a means of reducing macroeconomic, financial and personal risk (Berglof, 2010). Developing a theme from the 2009 report, the EBRD highlight the credit boom that developed in many CCE and CIS states from the early part of the current century and the cost involved in minimising the disturbance caused by the outflow of capital and the downward pressure on the exchange rate. The report showcases the fact that foreign currency loans account for more than $50 \%$ of the total advances in many CEE and CIS countries. The exceptions from the group of countries considered in this paper are the Czech Republic, Poland and Russia. When loans are broken down by maturity, it is clear that, possibly due to uncertainty over the long term value of units, the share of foreign currency increases with the length of the loan.

The main reason for domestic institutions use of foreign currency debt is that it appears to be cheaper than the domestic alternative (Focus on European Economic Integration: Foreign Currency Loans, 2011, p. 32 - 33). However, the EBRD report also discusses the disconnect that seems to exist between the private benefit of borrowing in foreign currency and the social cost that is created by the increased risk of financial dislocation. If this excessive borrowing of foreign currency debt is the result of a mis-pricing of risk, there is a role for government regulation to facilitate improvement. It is clear that there are some reasons why this speculative activity is rational individually but in total it creates costs in terms of crash risk that are born by society.

A study of foreign currency borrowing and bank balance sheet by Brown and De Haas was used by the European Bank for Reconstruction and De- 
velopment (EBRD) to show that higher foreign currency deposits, higher interest rate differentials and lower foreign exchange volatility were associated with higher levels of foreign currency borrowing. This is consistent with the idea that the opportunity for foreign currency borrowing, perceived opportunity cost and short-term risk profile are amongst key factors that entice domestic agents to borrow in overseas units (Brown and De Haas, 2010). These factors will form the starting point for the carry trade model that is developed here.

\section{Methods}

\subsection{The carry sample}

A full assessment of the carry trade in CEE and CIS countries is impossible without information about the positions that have been taken and the returns that have been achieved by international speculators and domestic households and firms. This private information is not available. It appears that no database or private permissioning of this type of data has been made available. However, a sample of possible carry trades can be constructed from information about exchange rates and interest rates that were available over the period under consideration. This is the method that was adopted in (Brunnermeier et al., 2008) and presented in Equation 5. The aim is to get a sample that is representative of the potential for the carry trade and to use this to establish how the profits from this speculative activity evolve over time. Finally, a model of carry trade profits will be used to better understand 
the factors that encourage the establishment of carry trade positions and the risks that are being taken.

The spot exchange rate and deposit rates for 1 month and 3 months were collected from the Thomson-Reuters 3000 Xtra system for the major CEE and CIS countries and for some other important European countries that have been prominent in the carry trade. The Icelandic Krona (ISK), the Norwegian Krone (NOK) and Turkish Lira (TUK) are generally regarded as being carry trade candidates and will be used as one benchmark against which to test the other countries. The selection was based on the availability of data. Slovakia and Slovenia were excluded because they have already joined the euro. Lithuania and Serbia were not included because there is a lack of deposit data. The data are end of month rates (the closing rate on the last day of the month).

The US dollar, the euro, the Swiss franc and the Japanese yen were used as funding currencies. Habib and Stracca have tried to assess the fundamentals of low yield, safe haven or funding currencies and have concluded that the net external asset position, the size of the stock market and, in some cases, the interest rate spread are the key feature indicating external stability, financial development and the presence of the carry trade for developed counties respectively (Habib and Stracca, 2012). The funding currencies chosen for this study fulfill these basic criteria.

One issue that arises with the use of monthly data is whether this creates a bias in the results. However, an examination of daily exchange rate and interest rate data does not suggest any seasonal pattern that would cause end of month rates to be systematically different from the average. One way 
to deal with this would be to use daily data in the calculation. However, the higher the frequency, the more likely that measurement error or the bid-ask spread will affect the findings.

\subsection{A carry trade model}

There are a number of factors that can be assumed to influence carry trade activity and the performance of the trade itself. Section 2.4 has an overview of the findings of (Brown and De Haas, 2010) which identify the exchange rate regime and the interest rate spread as being the key factors behind the participation of households in the carry trade. In Section 2.3 (Brunnermeier et al., 2008), (Spronk et al., 2013) and others have found that international risk aversion is an important feature in reducing the prevalence of the carry trade. This study seeks to build a model that has three main components: the exchange rate regime, the interest rate spread and a measure of international risk. These factors will then be used to understand more about carry trade risk and return.

\subsection{Exchange rate regime}

The nature of the exchange rate regimes is an important factor that can affect the performance of the carry trade. A fixed exchange rate can be an invitation to conduct the carry trade if there are interest rate differentials, particularly if the monetary authorities make a pledge to maintain the exchange rate. A flexible exchange rate means that there is much greater risk for the participant in the carry trade and therefore less carry activity is likely 
to be seen in these circumstances. The IMF classifies exchange rate regimes according to a range of rigidity running from a currency board through a fixed peg or crawling peg to a fully floating exchange rate (IMF, 2009). (IMF Classification of Exchange Rate and Monetary Policy Frameworks, 2004 to 2009). This classification can be simplified into three broad groups within the countries under study: those that have a permanently fixed exchange rate through the whole of the period (denoted group one), those that are fixed initially but gradually loosen the ties as the period progresses, or viceversa (denoted group two) and those that largely allow the exchange rate to fluctuate (denoted group three). The group categorisation is next to the country name. This categorisation will be used throughout the study.

\subsection{Risk and uncertainty}

Risk and uncertainty are a central theme and were discussed in detail in Section The carry trade is closer to that part of risk that is quantifiable and these calculations will be presented here. However, there is also a very important element that is uncertain: when will the crash happen? As has been seen from the analysis of the informational content of speculation in 3 , this is not very easy to discern. In order to increase the amount of information that is used to detect the the times when the risk of a crash has increased, carry trade participants are likely to take a large interest in the actions of others. They will use this observation to assess what information the others have: if they are involved in the trade, they are likely to be acting on information that encourages them to believe that conditions will remain 
Table 1: IMF Exchange Rate Arrangements and Monetary Policy Frameworks $1994-2010$

\begin{tabular}{l|rrrr} 
Country & Currency & Regime (1994) & Regime (2008) & Reference \\
\hline CEE/CIS & & & & \\
Bulgaria (1) & BGN & Currency board & currency board & EUR \\
Czech Republic (3) & CZK & Managed float & Float & EUR \\
Croatia (2) & HRK & Managed float & Fixed peg & EUR \\
Estonia (1) & EEK & Currency board & Currency board & EUR \\
Hungary (2) & HUF & Fixed peg & Float & EUR \\
Latvia (1) & LVL & Fixed peg & Fixed peg & Basket \\
Poland (3) & PLN & Float & Float & \\
Romania (2) & RON & Crawling peg & Managed float & EUR \\
Russia (2) & RUB & Managed float & Fixed peg & Basket \\
Ukraine (2) & UAH & Fixed peg & Managed float & US dollar \\
Other & & & & \\
Iceland & ISK & Float & Float & \\
Norway & NOK & Float & Float & \\
Turkey & TRY & Float & Float & \\
\hline
\end{tabular}

The categories come from the (IMF, 2009). The data are used as the basis for dividing the countries into three broad categories of exchange rate: those that have a permanently fixed exchange rate through the whole of the period under study; those that are fixed initially but gradually loosen the ties as the period progresses; those that substantially allow the exchange rate to fluctuate. Countries are allocated to one of three categories according to whether they have a main fixed exchange rate (1), a mixed regime or crawling peg (2) and a free float (3).

calm and the carry will remain successful; if they exit carry positions, they probably have information that suggests that the calm conditions are coming to an end and the risk to the carry trade has increased.

As a result, one of the chief characteristics of the carry trade is that it provides a self-fulfilling negation of UIP. However, it is very dependent on expectations. If financial markets are expected to be calm, the benefits of the interest rate differential will appear to be most attractive; if uncertainty increases, doubts about the carry trade can become more prominent as the probability that a sharp movement in exchange rates could outweigh the 
benefits of the interest rate differential will increase. The more intense the fear that the investment currency is likely to start appreciating against the funding unit, the greater the risk that the build up of speculative positions will be unwound in a cascade that provides a self-fulfilling crash.

There are a number of ways that expectations about the future may be affected: a change in the exchange rate regime; a market induced change in the value of the exchange rate; an adjustment in economic fundamentals that makes it more or less likely that there will be a large change in the exchange rate. The first means that political events are important, particularly those that could represent a change in government or policy. This is most acute when there is a fix rate or a crawling peg as any change is likely to result in a significant discrete adjustment such as that associated with the peso problem (see Section for a more complete discussion). The other cases mean that the broad range of influences on the exchange rate have to be continually monitored when the currency is allowed to float.

A second strand of uncertainty that is likely to affect the carry trade flows from the level of risk aversion or risk appetite in the international financial system. Increased uncertainty about the future, meaning that there is a perception that knowledge is less precise, is likely to lead to caution of the type identified by Keynes in his assessment of uncertainty and the liquidity premium (Keynes, 1936, p. 148, p. 240). This caution is likely to affect not only those in the specific exchange rate market but also those in the periphery and related markets. For example, as risk aversion rises generally, the cost of funding speculative positions is likely to increase (in terms of interest payment and margin requirement), funding currencies are likely to 
appreciate due to safe-haven effects and more risky, high yield and emerging currencies may suffer a tendency to weaken, even before carry trades are unwound. The unwinding of the carry trade accelerates the process.

This chapter will concentrate primarily on the international disturbances to expectations and the rise in international risk aversion. This is likely to have a two-fold effect: it will cause some unwinding of carry positions and it may also cause some flight-to-quality for funding currencies. As an extension of this work, measures of domestic disturbance could be included. These could try to capture changes in domestic political conditions or changes in domestic risk aversion. For example, the yield spread between domestic and core bonds, the price of credit default swaps or opinion polls of support for governing parties could be used.

\subsection{Measuring international risk aversion}

The measure of international risk aversion that will be used in this study is the VIX index. VIX is the ticker symbol for the Chicago Board Options Market Volatility Index. This is an index of one month implied volatility on the S\&P 500 stocks. See (Chicago Board of Trade, 2009) for full details on the method of calculation. ${ }^{2}$ The VIX is the square root of the S\&P 500 variance over the next 30 days. The VIX is quoted in annualised standard deviation. This translates into the annualised expected movement in the S\&P 500 in the next 30 days. When the index increase, implied volatility has increased, presumably because demand for options has risen relative to

\footnotetext{
${ }^{2}$ See (Brenner and Galai, 1989) for initial thoughts on the construction of volatility index. (Diamond, 2012) shows that the VIX index is the volatility of a variance swap. (Demeterfi et al., 1999) gives additional details of the pricing and use of volatility swaps.
} 
supply. It is believed that the increase in the demand for options, given that this is most likely to happen when fund managers want to protect against the risk of a sharp movement in equity prices, is a sign of increased uncertainty, concern about the future or risk aversion.

shows the performance of the VIX index through the period under study. It also shows the 90th and 60th percentiles which are used to determine periods of Crisis and Moderation respectively. These levels are chosen because intuitively they seem to be reasonable levels to associate with the terms Crisis and Moderation and by using Figure 1 to ensure that they are not dominated by specific periods. The 90th percentile of VIX reading for the period January 2000 to September 2010 is just above 32 while the sixtieth percentile is just over 23. The first means that market expectations, drawn from options prices of the constituents of the S\&P 500 index, are that the volatility of the S\&P 500 will be above an annualised $32 \%$ or $32 \% / \sqrt{12}=9.2$ percentage points over the coming month, meaning that, if the distribution of returns are normal, the returns should be could be up to plus or minus $9.2 \%$ in $68 \%$ of the time. For the period of moderation the same calculation is for an expected monthly range of less than $6.6 \%$ on the same basis.

In this study, during periods of moderation, it is expected that carry trade positions will be built up, while during the crisis it is more likely that they will be unwound. More broadly, this is also the pattern that would be expected to be seen in the whole economy. Minsky's FIH asserts that it is the periods of calm that encourage speculative lending to increase and the crisis that initiates a sharped, skewed reversal. In this way the carry is a micro-version of the FIH and the drivers and consequences of this speculative activity are 
Figure 1: The VIX index and critical thresholds used in the study

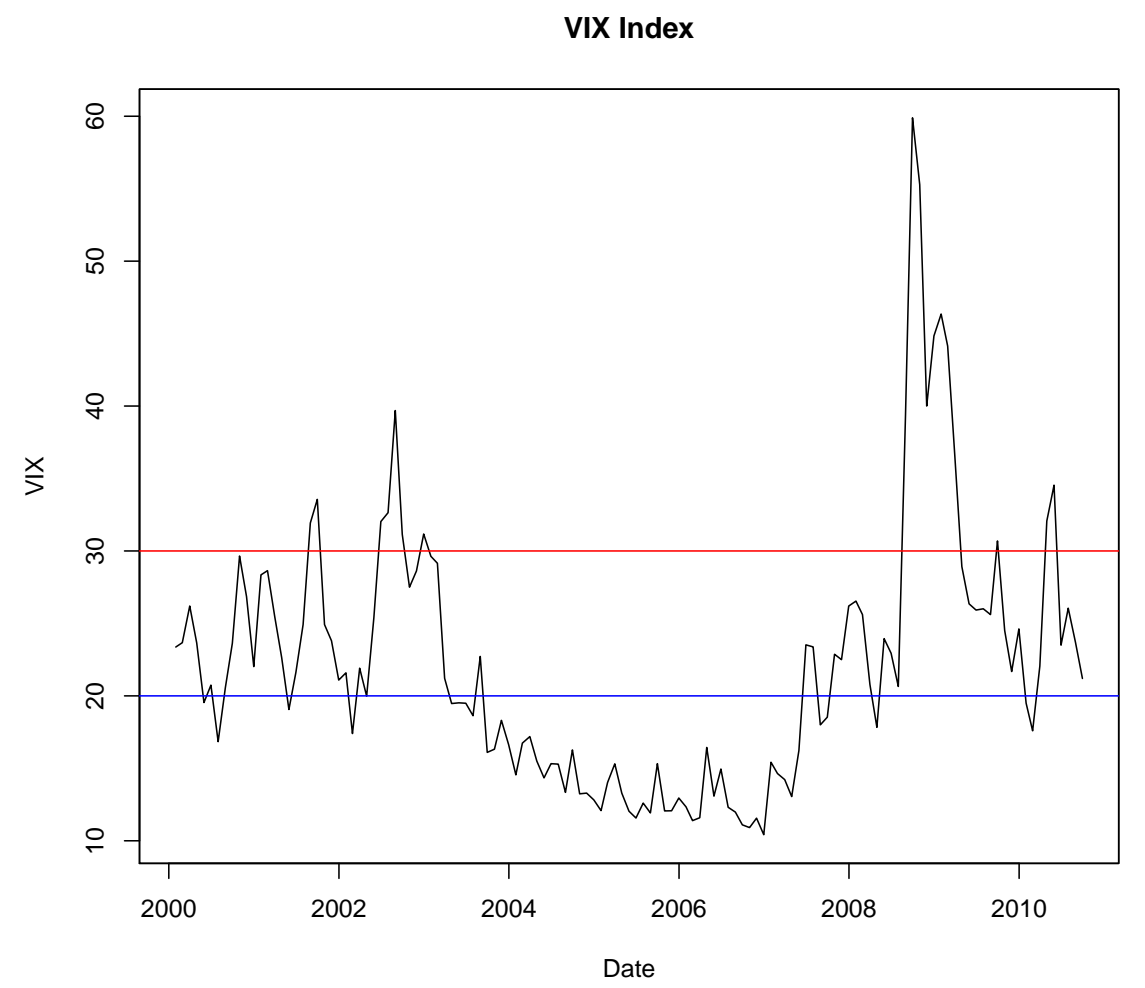

likely to provide very good pointers to the drivers and consequences of the speculative activity at the macro level.

There are a number of other indicators that could be used in place of the VIX index. These would include the spread between the top rated AAA bonds and the non-investment grade BBB bonds, one of the emerging market bond indices, implied volatility on some other financial instruments or even the level of speculative positions in some US futures contracts (where there is data availability from the CFTC). The aim in all these cases would be to establish an objective or quantifiable measure of international risk aversion. 


\section{Results}

\subsection{UIP test}

As a starting point of the investigation, a standard test of whether the forward rate provides an unbiased prediction of the future exchange rate is made. The forward rate is constructed from exchange rate and deposit data for 1 month and 3 month rates against all the funding currencies. This is based on the assumption that CIP holds. For example the 1-month forward rate of the Hungarian Forint against the EUR would be calculated as

$$
E U R H U F_{t}^{f 1 m}=\frac{\left(1+H U F 1 M_{t}\right)^{\frac{1}{12}} \times E U R H U F_{t}}{\left(1+E U R 1 M_{t}\right)^{\frac{1}{12}}}
$$

where $E U R H U F_{t}^{f 1 m}$ is the 1 month forward rate for euro in terms of Hungarian Forint at time t, $H U F 1 M_{t}$ is 1 month Hungarian Forint deposit rate, $E U R 1 M_{t}$ is the 1 month Euro deposit rate and $E U R H U F_{t}$ is the current rate of Euro in terms of Hungarian currency.

There is confirmation of the deviation from UIP through the period that is being studied. The test of the unbiased forward rate (Equation 2) records an estimate for $\beta_{2}$ that is below one in six of the ten CEE equations against the US dollar and for eight of the ten CEE and CIS against the Euro. The second column of Tables 2 and 3 identify those cases where the t-test of the restriction on unity for the coefficient is rejected at conventional statistical levels. 


\subsection{Carry trade tests}

In addition, a profit series is calculated based on conducting the carry trade using each of the CEE and CIS sample currencies. The calculation is based on an investment that borrows in the funding currency, exchanges these units for the higher yield currency and then converts back to repay the funding at the end of the month or the end of three months respectively. Therefore, it is assumed that there is an open position that maintains the risk that exchange rate movements will enhance or offset the interest rate pick up. For the calculation of a normalised one month carry trade involving the Hungarian Forint using the Euro as the funding currency, the calculation is

$$
P 1 M E U R H U F_{t}=\frac{\left(1+H U F 1 M_{t}\right)^{\frac{1}{12}} \times E U R H U F_{t}}{\left(1+E U R 1 M_{t}\right)^{\frac{1}{12}} \times E U R H U F_{t+1 M}}
$$

where $H U F 1 M_{t}$ is the 1 month Hungarian Forint deposit rate at time t, $E U R 1 M_{t}$ is the 1-month euro denominated deposit rate at time t, EURHUF is the exchange rate in terms of Hungarian Forint required for one euro at time t and $E U R H U F_{t+1 M}$ is the spot rate in 1 month's time. This is fundamentally the same as Brunnermeier's, which is Equation 5 (Brunnermeier et al., 2008). The value of P1MEURHUF is one when uncovered interest parity holds and the relatively higher interest rate in Hungary is exactly offset by a depreciation of the Hungarian currency against the euro over the course of the month. Carry trade positions speculate that the depreciation in the exchange rate will be less than the interest rate differential or positive carry: values of P1MEURHUF above 1 show a gain on the month, values less than 1 show a loss. A reading of 1.01 is a $1 \%$ gain for the month and a reading of 
.99 is a $1 \%$ loss for the month.

\subsection{Risk adjusted return}

Though the nature of the carry trade suggests that the assumption of normal, symmetric returns should be questioned, a Modified Sharpe Ratio (MSR) can be computed to make some initial and rather cautious comparison of the return to the carry trade compared to the return that is available on other assets. The MSR is calculated as a simple comparison of return per unit of risk, assuming that the risk free rate is zero so that returns are calculated from the break-even point. 
Table 2: Descriptive Statistics of Sample One Month Carry Trade against the US dollar

\begin{tabular}{|c|c|c|c|c|c|c|c|c|}
\hline Country & Coefficient & Mean & $\begin{array}{l}\text { Standard } \\
\text { Deviation }\end{array}$ & $\begin{array}{l}\text { Modified } \\
\text { Sharpe } \\
\text { Ratio }\end{array}$ & Skew & Kurtosis & Maximum & Minimum \\
\hline Bulgaria (1) & 0.9854 & 1.0024 & 0.0318 & 0.0755 & -0.0182 & $4.2100^{*}$ & 1.1018 & 0.8956 \\
\hline Estonia (1) & $0.9684^{*}$ & 1.0049 & 0.0319 & 0.1536 & 0.0429 & $4.2328^{*}$ & 1.1054 & 0.9036 \\
\hline Latvia (1) & $0.9522^{*}$ & 1.0033 & 0.0274 & 0.1204 & 0.0580 & $6.7653^{*}$ & 1.1137 & 0.9009 \\
\hline Croatia (2) & $0.9750^{*}$ & 1.0058 & 0.0315 & 0.1841 & -0.1471 & $3.9846^{*}$ & 1.0863 & 0.8973 \\
\hline Romania (2) & $0.9173^{* * *}$ & 1.0080 & 0.0342 & 0.2339 & $-0.3948^{*}$ & $6.0664^{*}$ & 1.1193 & 0.8682 \\
\hline Russia (2) & $0.9303^{* * *}$ & 1.0023 & 0.0232 & 0.0991 & $-1.5591^{*}$ & 14.6058 & 1.0840 & 0.8648 \\
\hline Ukraine (2) & 0.9808 & 1.0021 & 0.0302 & 0.0695 & $-3.3897^{*}$ & $23.5276^{*}$ & 1.0981 & 0.7971 \\
\hline Czech (3) & 0.9818 & 1.0071 & 0.0377 & 0.1883 & -0.1857 & $3.5011^{*}$ & 1.1076 & 0.8826 \\
\hline Hungary (3) & 0.9636 & 1.0077 & 0.0426 & 0.1808 & $-0.8653^{*}$ & $6.2039^{*}$ & 1.1209 & 0.8183 \\
\hline Poland (3) & $0.9577^{* *}$ & 1.0074 & 0.0408 & 0.1814 & $-0.6905^{*}$ & 4.8083 & 1.1046 & 0.8554 \\
\hline Norway (3) & 0.9751 & 1.0043 & 0.0333 & 0.1291 & $-0.3425^{*}$ & $4.2913^{*}$ & 1.0801 & 0.8756 \\
\hline Iceland (3) & 0.9715 & 1.0050 & 0.0473 & 0.1057 & $-0.7531^{*}$ & $7.6745^{*}$ & 1.1908 & \\
\hline Turkey (3) & $0.7960^{*}$ & 1.0122 & 0.0542 & 0.2066 & $-1.0979^{*}$ & $7.4436^{*}$ & 1.1473 & 0.7576 \\
\hline S\&P 500 & & 0.9977 & 0.0474 & -0.0485 & $-0.5081^{*}$ & $3.5923^{*}$ & 1.0935 & 0.8289 \\
\hline
\end{tabular}

Countries are classified according to (1) generally fixed exchange rate or currency board; (2) Crawling peg or liberalisation of the exchange rate regime during the period of study; (3) largely floating. The classification is based on the IMF IMF Classification of Exchange Rate Arrangements and Monetary Policy Frameworks 2004 to 2009 see Table 1 for fuller details. The "Coefficient" column is the ordinary least squares (OLS) estimate of the $\beta_{1}$ coefficient from the evaluation of equation $\Delta s_{t+j}=\beta_{0}+\beta_{1} f_{t+j}+\varepsilon_{t}$, where $\Delta s_{t+j}$ is the change in the spot exchange rate over $\mathrm{j}$ periods ahead, $f_{t+j}$ is $\mathrm{j}$-period forward rate, $\varepsilon_{t}$ is an error term and $\beta_{0}$ and $\beta_{1}$ are coefficients to be estimated. The statistical significance of $\beta_{1}$ is assessed with conventional t-statistics where *, ** and *** indicate $10 \%, 5 \%$ and $1 \%$ levels of statistical significance respectively. The other columns show the descriptive statistics for the profits from a carry trade calculated as $P 1 M E U R H U F_{t}=\frac{\left(1+H U F 1 M_{t}\right)^{\frac{1}{12}} \times E U R H U F_{t}}{\left(1+E U R 1 M_{t}\right)^{\frac{1}{12}} \times E U R H U F_{t+1 M}}$. The Modified Sharpe Ratio is calculated as the mean return per unit of risk assuming that there is a constant risk-free rate and that the breakeven point is the reference against which returns are judged. Skewness and kurtosis are measured in the conventional way with significance calculated as cases where the test statistic is greater than two standard error of skew 
From Tables 2 and 3, the MSR reveals that for positions funded against the US dollar, a carry investment in Romania has the highest return for unit of conventionally measured risk at 0.2339 per month compared to 0.2066 for Turkey and 0.1883, 0.1841, 0.1808 and 0.1814 for the Czech Republic, Croatia, Hungary and Poland respectively. When funding against the Euro, the Czech Republic and Hungary have ratios of 0.1751 and 0.1780 respectively while Iceland is at 0.1639. Croatia, Poland, Romania and Estonia are not far behind. 
Table 3: Descriptive Statistics of Sample One Month Carry Trade against the Euro

\begin{tabular}{|c|c|c|c|c|c|c|c|c|}
\hline Country & Coefficient & Mean & $\begin{array}{l}\text { Standard } \\
\text { Deviation }\end{array}$ & $\begin{array}{l}\text { Modified } \\
\text { Sharpe } \\
\text { Ratio } \\
\end{array}$ & Skew & Kurtosis & Maximum & Minimum \\
\hline Bulgaria (1) & $0.5425^{* * *}$ & 0.9999 & 0.0024 & -0.0417 & -0.1397 & $4.1821^{*}$ & 1.0061 & 0.9917 \\
\hline Estonia (1) & $\begin{array}{l}- \\
0.34798^{* * *}\end{array}$ & 1.0004 & 0.0023 & 0.1739 & 0.2811 & 3.0352 & 1.0064 & 0.9952 \\
\hline Latvia (1) & $0.9677^{* * *}$ & 0.9989 & 0.0121 & -0.0909 & $-0.8626^{*}$ & $7.8075^{*}$ & 1.0413 & 0.9411 \\
\hline Croatia (2) & $0.8153^{* * *}$ & 1.0016 & 0.0109 & 0.1468 & $-1.0107^{*}$ & $6.2748^{*}$ & 1.0260 & 0.9523 \\
\hline Romania (2) & $0.9733^{*}$ & 1.0039 & 0.0253 & 0.1541 & -0.0625 & 3.5665 & 1.0761 & 0.9284 \\
\hline Russia (2) & $0.9687^{*}$ & 0.9987 & 0.0282 & -0.0461 & $-1.8364^{*}$ & $11.3095^{*}$ & 1.0522 & 0.8367 \\
\hline Ukraine (2) & 0.9872 & 0.9985 & 0.0396 & -0.0379 & $-1.0945^{*}$ & $8.0828^{*}$ & 1.1096 & 0.7969 \\
\hline Hungary (3) & $0.8866^{* * *}$ & 1.0042 & 0.0236 & 0.1780 & $-0.8433^{*}$ & $7.3652^{*}$ & 1.0734 & 0.8908 \\
\hline Poland (3) & $0.9433^{* * *}$ & 1.0042 & 0.0292 & 0.1438 & $-0.5596^{*}$ & 0.4968 & 1.0770 & 0.9124 \\
\hline Czech (3) & 0.9812 & 1.0031 & 0.0177 & 0.1751 & $-0.4826^{*}$ & $4.2841^{*}$ & 1.0465 & 0.9460 \\
\hline Norway (3) & $0.8966^{* * *}$ & 1.0011 & 0.0202 & 0.0545 & 0.0266 & $7.6811^{*}$ & 1.0975 & 0.9210 \\
\hline Iceland (3) & $0.9819^{* * *}$ & 1.0007 & 0.0427 & 0.1639 & $-0.8212^{*}$ & $8.3528^{*}$ & 1.1727 & 0.8273 \\
\hline Turkey (3) & 0.9291 & 1.0077 & 0.0556 & 0.1384 & $-0.7185^{*}$ & $6.2073^{*}$ & 1.1890 & 0.8273 \\
\hline S\&P 500 & & 0.9977 & 0.0474 & -0.0485 & $-0.5081^{*}$ & $3.5923^{*}$ & 1.0935 & 0.8289 \\
\hline
\end{tabular}

Countries are classified according to (1) generally fixed exchange rate or currency board; (2) Crawling peg or liberalisation of the exchange rate regime during the period of study; (3) largely floating. The classification is based on the IMF IMF Classification of Exchange Rate Arrangements and Monetary Policy Frameworks 2004 to 2009 see Table 1 for fuller details. The "Coefficient" column is the ordinary least squares (OLS) estimate of the $\beta_{1}$ coefficient from the evaluation of equation $\Delta s_{t+j}=\beta_{0}+\beta_{1} f_{t+j}+\varepsilon_{t}$, where $\Delta s_{t+j}$ is the change in the spot exchange rate over $\mathrm{j}$ periods ahead, $f_{t+j}$ is $\mathrm{j}$-period forward rate, $\varepsilon_{t}$ is an error term and $\beta_{0}$ and $\beta_{1}$ are coefficients to be estimated. The statistical significance of $\beta_{1}$ is assessed with conventional t-statistics where $*, * *$ and $* * *$ indicate $10 \%, 5 \%$ and $1 \%$ levels of statistical significance respectively. The other columns show the descriptive statistics for the profits from a carry trade calculated as $P 1 M E U R H U F_{t}=\frac{\left(1+H U F 1 M_{t}\right)^{\frac{1}{12}} \times E U R H U F_{t}}{\left(1+E U R 1 M_{t} \frac{1}{12} \times E U R H U F_{t+1 M}\right.}$. The Modified Sharpe Ratio is calculated as the mean return per unit of risk assuming that there is a constant risk-free rate and that the breakeven point is the reference against which returns are judged. Skewness and kurtosis are 
Evidence from the sample one month carry trade show that in all currency cases there is an expected positive return when funded against the US dollar (see Table 2). Against the Euro the outcome is more mixed. On average a loss is made when depositing funds in Bulgaria, Russia, Ukraine and Latvia. An analysis of the results shows a range of returns on carry trade funded by the US dollar from 1.0080 for Romania to 1.0021 for the Ukraine, or $0.8 \%$ per month (around 10\% annualised) and $0.2 \%$ per month (around $2.5 \%$ annualised). These returns compare quite favourably with the more well known carry countries like Norway, Iceland and Turkey where the sample returns over this period are 1.0043, 1.005 and $1.0112(0.43 \%, 0.5 \%$ and $1.1 \%$ respectively. The $1 \%$ average return on a US dollar funded investment in Turkish deposits is the most favourable in this sample. This would give just a little more than $14 \%$ annualised return. The others are $5 \%$ and $6 \%$ respectively. These returns also compare favourably with the sample return available on the S\&P 500 index which made an average loss through the same period calculated on the same funding process.

For the positions funded by the Euro, Polish and Hungarian positions achieve a mean return of $0.42 \%$ (just over $5 \%$ annualised). This is just a little less than the $0.77 \%$ (nearly $10 \%$ annualised) achieved for a Turkish carry position but more than the $0.11 \%$ and $0.07 \%$ for Iceland and Norway respectively. There are average losses for deposits made in Bulgaria, Russia, Ukraine and Latvia. See Table 3. The positions for carry trades funded by Swiss francs (not reported but available on request) show average carry profits for Czech, Croatia, Hungary, Poland, Romania and Estonia (as well as Norway, Iceland and Turkey). For carry trades funded by the Japanese 
yen, all the carry positions are profitable on average.

In conclusion, the preliminary investigation shows that UIP generally does not hold for the main CEE and CIS exchange rates during the period under study and it appears that there are returns from investing in the carry trade. The question of whether these returns are sufficient to compensate for the risk that is being taken will be investigated in the next section by building a carry trade model and using that to understand more about the nature of the risk and return.

\subsection{A carry trade model}

The aim of this section is to build a model to explain the carry trade and to use this to learn more about the profits and risk associated with the activity. As was identified in Section 3.2, the main components of the carry model should be the exchange rate regime, the level of international risk aversion and the interest rate differential. Given the assumption that calm conditions will encourage carry trade positions to be established and that this will tend to mean that the carry trade is successful by the encouraging appreciation of the investment currency at the expense of the funding currency, it may be suspected that there will be some momentum behind the carry trade and that an increase in profits for the carry trade will encourage other participants to enter the market.

The initial assessment of the carry trade is carried out with simple ordinary least squares $(\mathrm{OLS})^{3}$ using the profits from the carry trade as the

\footnotetext{
${ }^{3}$ There is likely to be some bias to the estimates of the coefficient on the lagged dependent variables as a result of using this method and therefore the results should be
} 
dependent variable and using the lag of the dependent variable, the VIX index and the spread between the interest rates in the investment and funding currencies. The carry trade should benefit from calm conditions and, when these are in place, carry positions are likely to be gradually built. This would suggest serial correlation in the profit series would be seen in periods of calm. Changes in the VIX index are designed to capture adjustments in international risk preference that should make the carry trade less attractive. Therefore, lower levels of the VIX are associated with calm and the building of profitable positions; higher levels of the VIX should be associated with reversals, as carry trade positions are unwound, negative profits, increased liquidity constraints and a rise in risk aversion amongst investors and funders of the position, and an increased probability of crash risk. The interest rate differential makes the carry trade attractive in the first place and provides a greater buffer against a depreciation of the investment currency against the funding unit. Therefore, the greater the interest rate differential the greater the expected profit and the greater the crash risk that should be expected. The equation to be estimated is

$$
y_{i t}=\beta_{0}+\beta_{1} x_{1}+\beta_{2} x_{2}+\beta_{3} x_{3}+\varepsilon
$$

where $y_{t}$ is the return to the carry trade for country I at time t, $x_{1}$ is the lag of the dependent variable, $x_{2}$ is the VIX index and $x_{3}$ is the interest rate differential; $\beta_{0}, \beta_{1}, \beta_{2}$ and $\beta_{3}$ are the coefficients to be estimated. The

treated with some caution. In an estimation of $y_{t}=a+b_{1} y_{t-1}+e_{t}, E\left(y_{t}, e_{t}\right) \neq 0$. The bias will disappear asymptotically so long as there is no serial correlation in the residuals. Therefore, the inspection of the residuals is most important in this case (White, 1961). 
results of the investigation are presented in Tables 4 and 5. The VIX index is statistically significant and negative in each case. There is mixed evidence on serial correlation. Russia, Ukraine and Iceland show signs of momentum behind the carry trade that could indicate a build up of risky positions. In Croatia, Latvia and Estonia, there is evidence of negative feedback. This may be a function of the natural fluctuation within an exchange rate band. There may be mean-reversion to the centre of the band when the exchange rate is fixed. Interest rate differentials have a positive effect in all cases, but it is not always statistically significant. As would be expected, the more fixed the exchange rate, the more important the interest rate differential appears to be for the carry trade. An interest rate differential will encourage the building of carry trade positions when the exchange rate is fixed.

There are surprisingly few differences in the results of funding with the US dollar compared to funding with the Euro. Russia and the Ukraine, where the exchange rate is more referenced against the US dollar, show quite a strong influence from the interest rate differential on the profitability of the carry trade when funded against the US unit, but this disappears when assessing the interest rate differential with the Euro; the more fixed the exchange rate, the more interest rate differentials are important, the more variable, the more international crisis affects the profitability of the carry trade. The more fixed the exchange rate the more the interest rate differential is important. 
Table 4: Influences on the carry trade funded by US dollars

\begin{tabular}{l|llll} 
Country & $\begin{array}{l}\text { Exchange } \\
\text { Rate }\end{array}$ & $\begin{array}{l}\text { Auto- } \\
\text { regression }\end{array}$ & VIX & Rate Spread \\
& Regime & & & \\
\hline Bulgaria & $(1)$ & 0.0243 & -0.0005 & $0.0027^{*}$ \\
Estonia & $(1)$ & -0.0134 & $-0.0009^{* *}$ & $0.0044^{* *}$ \\
Latvia & $(1)$ & -0.1618 & $-0.0008^{* * *}$ & $0.0034^{* * *}$ \\
Croatia & $(2)$ & -0.0477 & $-0.0007^{*}$ & $0.0021^{* *}$ \\
Romania & $(2)$ & 0.0033 & $-0.0011^{* * *}$ & $0.0004^{*}$ \\
Russia & $(2)$ & $0.3420^{* * *}$ & $-0.0007^{* * *}$ & $0.0011^{* *}$ \\
Ukraine & $(2)$ & $0.2504^{* * *}$ & $-0.0016^{* * *}$ & $0.0018^{* * *}$ \\
Hungary & $(2)$ & 0.0058 & $-0.0012^{* * *}$ & $0.0028^{* *}$ \\
Czech Republic & $(3)$ & 0.0138 & $-0.0009^{* *}$ & 0.0030 \\
Poland & $(3)$ & $-0.0013^{* * *}$ & 0.0010 & \\
Turkey & $(3)$ & 0.0947 & $-0.0013^{* * *}$ & 0.0003 \\
Iceland & $(3)$ & $0.1838^{* *}$ & $-0.0009^{*}$ & 0.0000 \\
Norway & $(3)$ & 0.0792 & $-0.0010^{* *}$ & $0.0032^{*}$ \\
\hline
\end{tabular}

These are the coefficients on the equation $y_{i t}=\beta_{0}+\beta_{1} X_{1}+\beta_{2} X_{2}+\beta_{3} X_{3}+\varepsilon_{t}$, where $y_{i t}$ is the profit from the carry trade at time t, $X_{1}$ is the lag of the dependent variable, $X_{2}$ is the VIX index of implied volatilities on the S\&P 500 index, $X_{2}$ is the 1-month interest rate differential between the currency and the funding unit (US dollars). $\beta_{0}, \beta_{1}$ and $\beta_{2}$ are coefficients to be estimated. *,** and $* * *$ signify that the estimated coefficients are significantly different from zero using t-statistics at the $10 \%, 5 \%$ and $1 \%$ level of significance respectively.

\subsection{Moderation and Crisis}

The FIH postulates that there are periods of calm, during which speculative positions are built as shocks become increasingly difficult to imagine. However, these calm conditions and the build up of speculative positions that accompany them create the conditions under which the potential for a large crash is increased. The carry trade appears to have a very similar pattern. Indeed, it could be considered a micro version of the FIH. Therefore, this study will assess whether the carry trade can be characterised by two distinct periods: the calm or moderation when speculative positions are build; 
Table 5: Influences on the carry trade funded by the Euro

\begin{tabular}{l|llll} 
Country & $\begin{array}{l}\text { Exchange } \\
\text { Rate }\end{array}$ & $\begin{array}{l}\text { Auto- } \\
\text { regression }\end{array}$ & VIX & Rate Spread \\
& Regime & & & \\
\hline Bulgaria & $(1)$ & $-0.2603^{* * *}$ & 0.0000 & $0.0010^{* * *}$ \\
Estonia & $(1)$ & $-0.4639^{* * *}$ & 0.0000 & $0.0010^{* * *}$ \\
Latvia & $(1)$ & 0.0571 & 0.0000 & $0.0014^{* * *}$ \\
Croatia & $(2)$ & $-0.1684^{*}$ & -0.0010 & $0.0009^{*}$ \\
Romania & $(2)$ & 0.0645 & $-0.0007^{* * *}$ & $0.0004^{*}$ \\
Russia & $(2)$ & $0.1715^{*}$ & -0.0002 & 0.0000 \\
Ukraine & $(2)$ & 0.1074 & $-0.0010^{* *}$ & 0.0007 \\
Hungary & $(2)$ & 0.0746 & $-0.0006^{* * *}$ & $0.0021^{* *}$ \\
Czech Republic & $(3)$ & 0.0294 & $-0.0004^{* *}$ & $0.0038^{*}$ \\
Poland & $(3)$ & $0.1966^{* *}$ & $-0.0008^{* * *}$ & $0.0011^{*}$ \\
Turkey & $(3)$ & 0.0358 & $-0.0010^{* *}$ & 0.0000 \\
Iceland & $(3)$ & 0.1087 & -0.0008 & 0.0002 \\
Norway & $(3)$ & -0.0256 & -0.0003 & 0.0004 \\
\hline
\end{tabular}

These are the coefficients on the equation $y_{i t}=\beta_{0}+\beta_{1} X_{1}+\beta_{2} X_{2}+\beta_{3} X_{3}+\varepsilon_{t}$, where $y_{i t}$ is the profit from the carry trade at time t, $X_{1}$ is the lag of the dependent variable, $X_{2}$ is the VIX index of implied volatilities on the S\&P 500 index, $X_{2}$ is the 1-month interest rate differential between the currency and the funding unit (Euro). $\beta_{0}, \beta_{1}$ and $\beta_{2}$ are coefficients to be estimated. ${ }^{*},{ }^{*}$ and *** signify that the estimated coefficients are significantly different from zero using t-statistics at the 10\%, $5 \%$ and $1 \%$ level of significance respectively.

the crisis of panic when positions are unwound. This part of the paper seeks to understand the nature of returns to the carry trade in these two regimes.

Indeed, underlying this hypothesis, the distribution of returns to the carry trade can be postulated as having two phases: a relatively tight distribution about the mean during periods of calm and broad or fat-tailed distribution with a negative mean during times of crisis. To make a comparison of the two regimes, the sample carry trades are broken into two categories. The first is the period calm or moderation and labeled $\mathrm{M}$ and the second of crisis and is labeled C. Using the VIX index as a signal of international crisis the 
sample is divided into those crisis periods when the VIX is above the 90th percentile of the whole period under investigation and those calm periods when it is less than the 60th percentile. The levels are chosen with reference to the data (see Figure 1) to ensure that there are a sufficient number of observations in each category and to try to prevent the 2007 - 2008 financial crisis dominating the period of crisis. On inspection, it is clear that the recent crisis is important, but there are some representatives from earlier. It would have been interesting to have used a rolling quantile but the relative sparsity of data made this unfeasible.

There are a number of themes that emerge from the result of this exercise (Table 6 for US dollar funding and Table 7 for Euro funding). For US dollar funding, carry returns in the crisis period are below those in the period of calm for all cases and in all cases, apart from Bulgaria where results may be affected by one large discrete devaluation at the beginning of the sample, the mean return switches from being a profit to being a loss. For Euro funding, crisis returns are lower in all cases but Bulgaria, Latvia, Estonia and Iceland and the mean return again switches from profit to loss. These findings are consistent with the hypothesis that carry trades are successfully built in times of calm and unprofitably unwound in the crisis.

The decline in profitability is statistically significant for Poland, Romania and Norway when funding with US dollars and Poland, Hungary and Estonia when funding with Euro. The test used is an F-test analysis of variance that compares the variability between the mean of the two groups with the variability of the samples within the two groups modified along the lines of Welch to compensate for differences in the variance of the two groups (Welch, 
1951). It is not surprising that a floating exchange rate regime is more likely to encounter significant variation in carry returns.

The second finding is that the increase in international uncertainty and risk aversion is associated with an increase in in the risk attached to carry trade profits, whether measured in conventional or unconventional ways. The standard deviation of carry returns funded against the US dollar is larger in the crisis period relative to that recorded in the period of calm for all CEE and CIS countries in this sample. An F-test of the ratio of the standard deviation of the two return periods (crisis and moderation) is significant in all cases. It is very likely that this is at least partially a function of the US dollar leg of the trade becoming more volatile due to international issues. However, though US dollar funded carry trade with Iceland shows the same pattern of increased volatility, the increase in the standard deviation of Norwegian and Turkish crisis returns may be a little larger for the crisis, they are not statistically significant using the same F-test standard. For Euro funding of the carry trade, all cases bar Latvia and Estonia show greater risk in the crisis period. These results should not be surprising given the currency board arrangements that are designed to minimise the fluctuations in the exchange rate. The increased volatility for Bulgaria, which also has a currency board, is associated with the pre-board period. However, only in the case of the Czech Republic, Ukraine and Russia are difference in variance statistically significant under the test constructed.

The F-test of standard deviation equality assumes a normal distribution. As noted in the literature and the initial investigation, this is not likely to be an accurate description of returns to the carry trade. Therefore, a non- 
parametric test of the return distributions in crisis and calm can be carried out. The test conducted is the Mann-Whitney-Wilcoxon (MWW) rank sum test. The test will compare the ranks of the two series and the U statistic

$$
U_{1}=R_{1}-\frac{n_{1}\left(n_{2}+1\right)}{2}
$$

where $R_{1}$ is the rank of series $1, n_{1}$ is the number of observations in series 1 and $n_{2}$ is the number of observations in series 2. The smallest $\mathrm{U}$ statistic for the two series is chosen. $U-1$ is normally distributed in larger samples with tables for less than 30 observations. A large value for the test statistic is a general indication that the means, medians or general characteristics of the two distributions are different in the two samples.

There is consistent and persistent evidence that profitability of the carry trades is affected by the international crisis and changes in risk aversion. This is most evident in the countries that allow their exchange rates to float. It seems that linking to a funding currency will reduce the possibility of extremely negative exchange rate outcomes, though there may be other monetary costs associated with the implementation of the stabilisation policy.

Using the robust MWW to test whether the distribution of the carry trade profits in the two regimes are different (identified as an asterisk in the standard deviation column of Tables 6 and 7), reveals significant results for Poland, Romania, Russia and Turkey with US dollar funding and Hungary, Poland, Estonia, Norway and Turkey for EUR funding. The conclusion is that the distribution of returns in periods of calm and moderation in these cases are not the same, providing support for the hypothesis that carry trades 
can be characterised by two regimes, moderation and crisis, and that the distribution of carry trade profits for the period of moderation has a high mean, a compact and symmetric distribution while the mean for the crisis is lower (probably negative) and the distribution is wide and skewed. The profits are lower and the risk is higher. 
Table 6: Carry trade vs US dollar: A comparison of Crisis (C) and Moderation (M) modes

\begin{tabular}{|c|c|c|c|c|c|c|c|c|}
\hline \multirow{2}{*}{$\begin{array}{l}\text { Country } \\
\text { Bulgaria (1) }\end{array}$} & \multicolumn{2}{|c|}{$\begin{array}{c}\text { Crisis Moderation } \\
\text { Mean }\end{array}$} & \multicolumn{2}{|c|}{$\begin{array}{c}\text { Crisis Moderation } \\
\text { Standard Deviation }\end{array}$} & \multicolumn{2}{|c|}{$\begin{array}{c}\text { Crisis Moderation } \\
\text { Skew }\end{array}$} & \multicolumn{2}{|c|}{$\begin{array}{c}\text { Crisis Moderation } \\
\text { Kurtosis }\end{array}$} \\
\hline & 0.9869 & 0.9998 & $0.0542^{*}$ & 0.0245 & 0.2119 & 0.0993 & 3.0996 & 2.2825 \\
\hline Estonia (1) & 0.9894 & 1.0019 & $0.0539 * * *$ & 0.0237 & 0.2980 & 0.1177 & 3.0854 & 2.8024 \\
\hline Latvia (1) & 0.9893 & 1.0011 & $0.0548 * * *$ & 0.0192 & 0.5186 & -0.2981 & 3.4178 & $3, .5784$ \\
\hline Croatia (2) & 0.9911 & 1.0033 & $0.0492^{* * *}$ & 0.0239 & -0.5192 & 0.1090 & 2.5149 & 3.2016 \\
\hline Romania (2) & $0.9780^{*}$ & 0.0118 & $0.0585^{* *}$ & 0.0290 & $-0.3242^{* *}$ & 0.6032 & 2.2246 & 4.9414 \\
\hline Russia (2) & 0.9799 & 1.0040 & $0.0519 * * *$ & 0.0125 & $-0.5190 * *$ & -0.7216 & 3.3035 & 5.8705 \\
\hline Ukraine (2) & 0.9722 & 1.0049 & $0.0787^{* * *}$ & 010124 & -0.8091 & 1.1037 & 3.2066 & 6.5962 \\
\hline Czech (3) & 0.9823 & 1.0046 & $0.0522^{* *}$ & 0.0306 & -0.2056 & -0.2102 & 2.5504 & 2.7822 \\
\hline Hungary (3) & 0.9752 & 1.0079 & $0.0773^{* * *}$ & 0.0342 & -0.6404 & -0.5227 & 2.6642 & 2.6364 \\
\hline Poland (3) & $0.9693^{*}$ & 1.0080 & $0.0669^{* *}$ & 0.0330 & $-0.3928^{*}$ & -0.3027 & 1.9318 & 2.8995 \\
\hline Norway (3) & $0.9812^{*}$ & 1.0044 & 0.0593 & 0.0297 & -0.9127 & 0.2421 & 2.7733 & 3.0321 \\
\hline Iceland (3) & 0.9937 & 1.0094 & $0.1265 * * *$ & 0.0329 & 0.4620 & 0.0329 & 1.9136 & 3.0460 \\
\hline Turkey (3) & 0.9696 & 1.0212 & 0.0725 & 0.0440 & $-1.1087^{*}$ & -0.3614 & 2.9842 & 6.3445 \\
\hline S\&P 500 & 0.9849 & 0.9966 & $0.0899^{* *}$ & 0.0367 & 0.2461 & -0.4854 & 1.3363 & 3.4212 \\
\hline
\end{tabular}

Countries are classified according to (1) generally fixed exchange rate or currency board; (2) Crawling pego or liberalisation of the exchange rate regime during the period of study; (3) largely floating. The classification is based on the IMF IMF Classification of Exchange Rate Arrangements and Monetary Policy Frameworks 2004 to 2009 see table 1 for fuller details. The crisis mode is identified by the VIX index being above the 90th percentile while the moderation is below the 60th percentile. The test of the difference in means is an analysis of variance F-test that compares the variability of the means of the two groups with the variation of the samples within groups, modified along the lines of the (Welch, 1951) for possible differences in the standard deviation of the samples. The comparison of the standard deviations is based on an F-test of the two variances, the distribution of the profits during the crisis and moderation periods is compared using the rank test proposed by Mann-Whitney-Wilcoxon to produce a U statistic (noted in the skew column). In all cases the statistical significance of the difference between the two periods at the $1 \%, 5 \%$ and $10 \%$ levels is identified by $* * *, * *$ and $*$ respectively. 
Table 7: Carry trade vs the Euro: A comparison of Crisis (C) and Moderation (M) modes

\begin{tabular}{|c|c|c|c|c|c|c|c|c|}
\hline \multirow{2}{*}{$\begin{array}{l}\text { Country } \\
\text { Bulgaria (1) }\end{array}$} & \multicolumn{2}{|c|}{$\begin{array}{l}\text { Crisis Moderation } \\
\text { Mean }\end{array}$} & \multicolumn{2}{|c|}{$\begin{array}{l}\text { Crisis Moderation } \\
\text { Standard Deviation }\end{array}$} & \multicolumn{2}{|c|}{$\begin{array}{l}\text { Crisis Moderation } \\
\text { Skew }\end{array}$} & \multicolumn{2}{|c|}{$\begin{array}{c}\text { Crisis Moderation } \\
\text { Kurtosis }\end{array}$} \\
\hline & 0.9979 & 0.9989 & 0.0037 & 0.0019 & -0.6208 & 0.0177 & 2.3408 & 5.0171 \\
\hline Estonia (1) & 1.0023 & 0.9999 & 0.0022 & 0.0020 & $0.5329 * * *$ & 0.3551 & 1.9143 & 3.9310 \\
\hline Latvia (1) & 1.0036 & 0.9990 & 0.0106 & 0.0111 & 0.1292 & 0.1126 & 2.1531 & 5.5973 \\
\hline Croatia (2) & 0.9981 & 1.0020 & 0.0143 & 0.0091 & -1.1246 & -0.3460 & 2.9392 & 4.0375 \\
\hline Romania (2) & 0.9886 & 1.0076 & 0.0379 & 0.0227 & -0.1564 & 0.5149 & 1.3058 & 3.3333 \\
\hline Russia (2) & 0.9755 & 1.0018 & $0.0781 * * *$ & 0.0198 & -0.9529 & -0.1711 & 2.6817 & 3.3539 \\
\hline Ukraine (2) & 0.9530 & 1.0031 & $0.1130^{* * *}$ & 0.0286 & 0.0877 & -0.0538 & 1.9163 & 3.0344 \\
\hline Czech (3) & 0.9823 & 1.0026 & $0.0350 * *$ & 0.0133 & 0.1880 & -0.1890 & 1.3283 & 3.0750 \\
\hline Hungary (3) & $0.9656^{*}$ & 1.0070 & 0.0405 & 0.0212 & $-1.1734^{* * *}$ & -0.5259 & 2.9761 & 5.4320 \\
\hline Poland (3) & 0.9520 *** & 1.0068 & 0.0321 & 0.0263 & $0.4844^{* * *}$ & -0.5970 & 2.3183 & 3.3204 \\
\hline Norway (3) & 0.9974 & 1.0032 & $0.0597 * * *$ & 0.0169 & $0.8849^{*}$ & -0.07930 & 2.9493 & 3.8786 \\
\hline Iceland (3) & 1.0022 & 1.0072 & $0.1179^{* * *}$ & 0.0284 & 0.1495 & -0.7455 & 1.8228 & 4.8749 \\
\hline Turkey (3) & 0.9770 & 1.0193 & 0.0407 & 0.0483 & $-0.1328^{* *}$ & -0.2182 & 1.7780 & 6.0263 \\
\hline S\&P 500 & 0.9849 & 0.9966 & $0.0899 * *$ & 0.0367 & 0.2461 & -0.4854 & 1.3363 & 3.4212 \\
\hline
\end{tabular}

Countries are classified according to (1) generally fixed exchange rate or currency board; (2) Crawling pego or liberalisation of the exchange rate regime during the period of study; (3) largely floating. The classification is based on the IMF IMF Classification of Exchange Rate Arrangements and Monetary Policy Frameworks 2004 to 2009 see table 1 for fuller details. The crisis mode is identified by the VIX index being above the 90th percentile while the moderation is below the 60th percentile. The test of the difference in means is an analysis of variance F-test that compares the variability of the means of the two groups with the variation of the samples within groups, modified along the lines of the (Welch, 1951) for possible differences in the standard deviation of the samples. The comparison of the standard deviations is based on an F-test of the two variances, the distribution of the profits during the crisis and moderation periods is compared using the rank test proposed by Mann-Whitney-Wilcoxon to produce a U statistic (noted in the skew column). In all cases the statistical significance of the difference between the two periods at the $1 \%, 5 \%$ and $10 \%$ levels is identified by ***, ** and * respectively. 
Figure 2: The Distribution of USD Carry Trade Returns in Moderation and Crisis

USD Carry trade returns in Crisis and Moderation
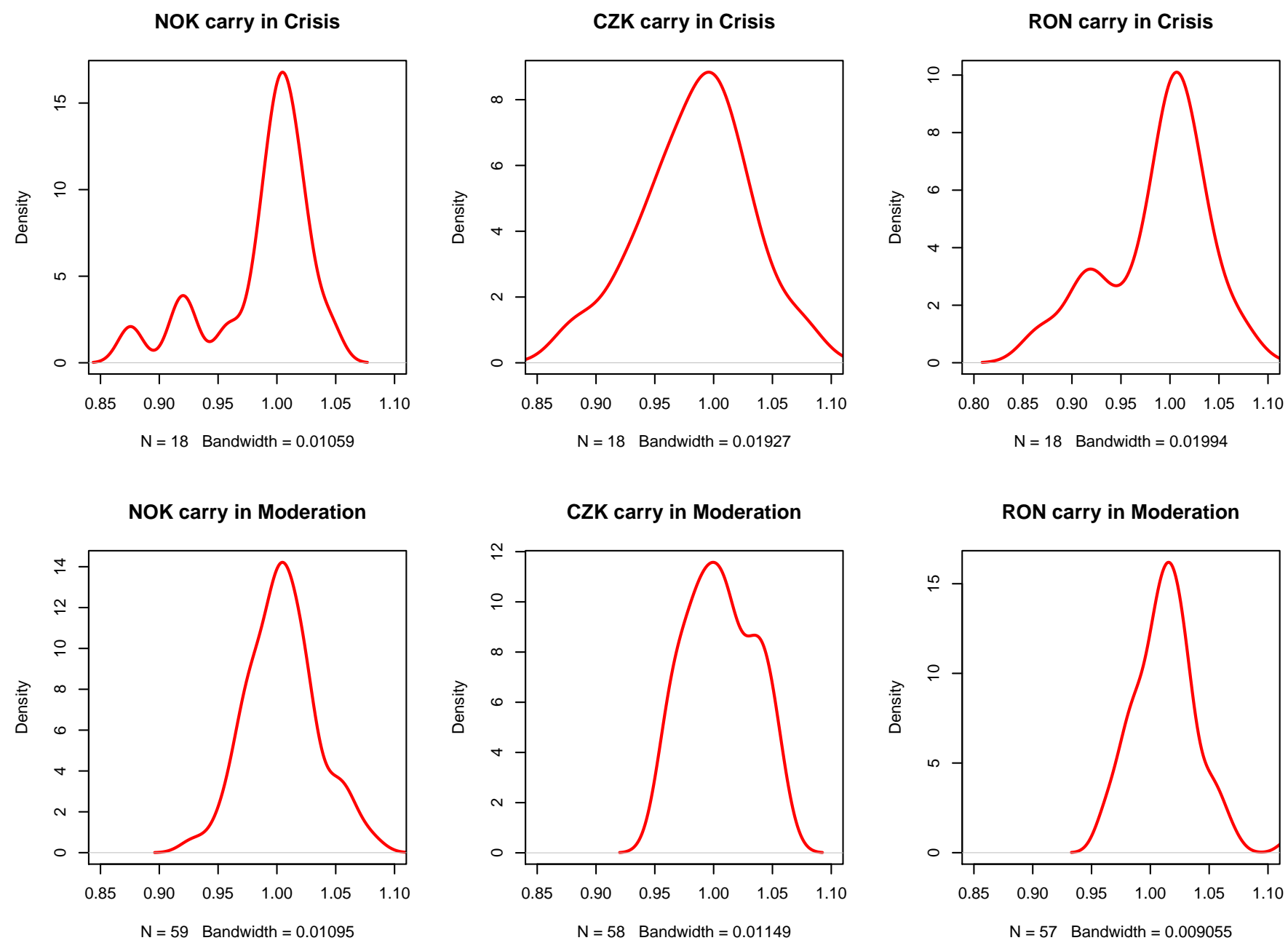
The difference in the carry trade profit during periods of moderation and crisis is very clear when presented graphically with kernel density estimates. A kernel density estimate is a smoothed histogram. Rather than putting the data points into a bin, a normal distribution with a mean on each point is established and these kernels are added together to get a smoothed line. The size of the standard deviation that is applied to the normal distribution about the data point is called the bandwidth. There is a trade off between the establishment of a smooth line with a large bandwidth and the dissipation of the information that this implies. The default Silverman's rule of thumb is used in this case and reported at the bottom of the graph (Silverman, 1986, p. 48). This analysis is carried out with the density function in base package in R (R Core Team, 2013) see (Venables and Ripley, 2002) for more details of the smoothing process.

Figure 2shows the distribution of carry trade returns for Norway (NOK), Czech Republic (CZK) and Romania (RON) when funded against the US dollar during the period of Crisis (C) and period of Moderation (M) respectively; Figure 3 shows the distribution of carry trade returns for Hungary (HUF), Poland (PLN) and Iceland (ISK) against the Euro during the period Crisis (C) and Moderation (M). The $\mathrm{x}$ axis is fixed to ensure clear comparison. It is clear that during the times of increased international risk aversion, the returns to the carry trade are not only lower on average but they are more dispersed, more negatively skewed and more likely to be losses. 
Figure 3: The Distribution of EUR Carry Trade Returns in Moderation and Crisis

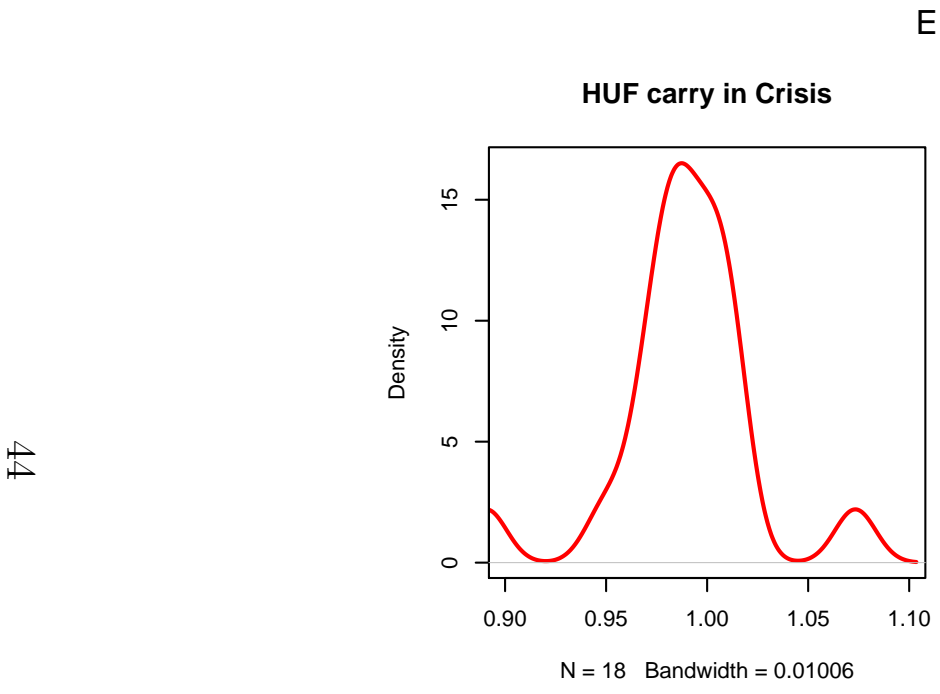

EUR Carry trade returns in Crisis and Moderation
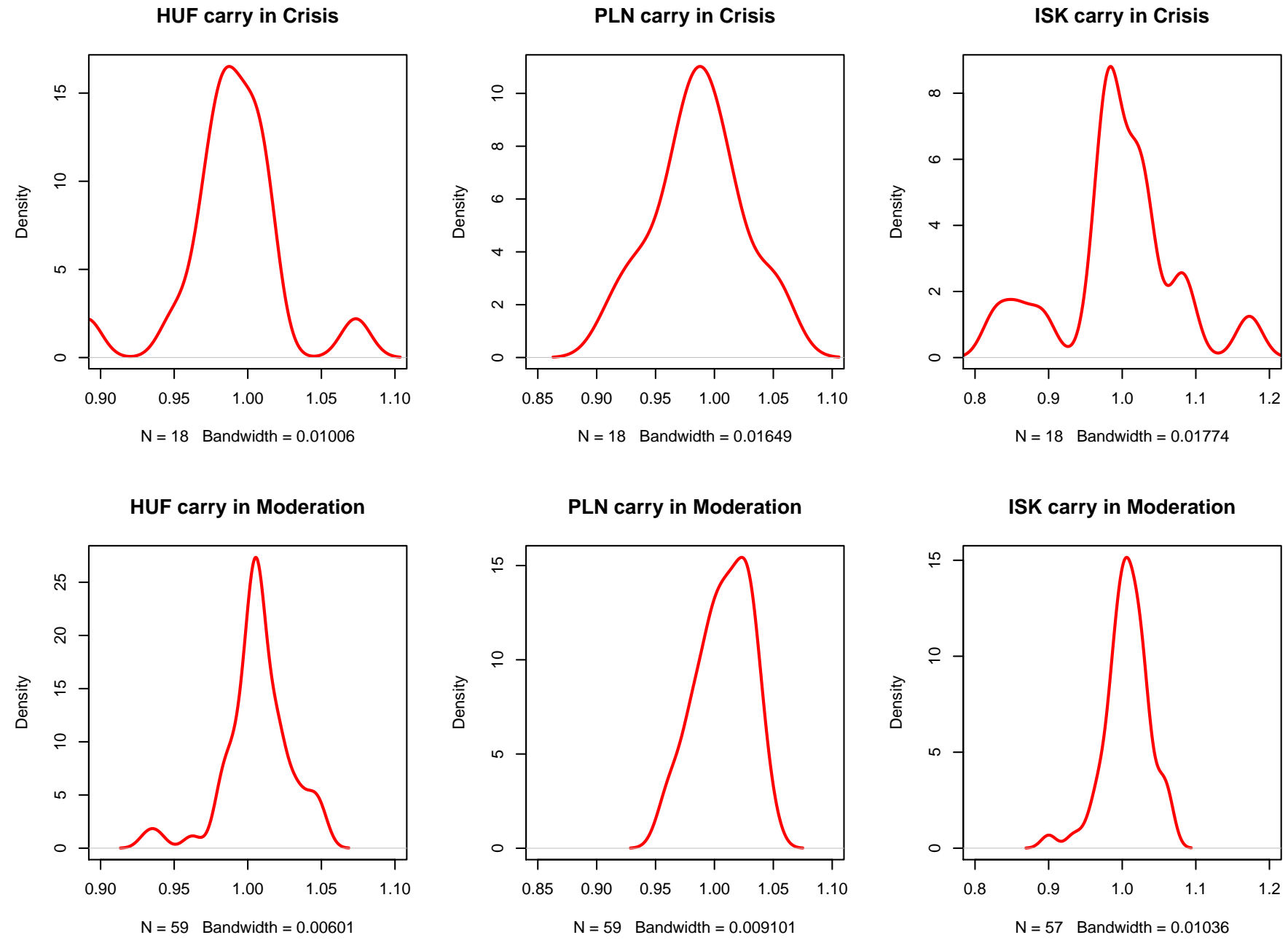


\section{The carry trade and speculation}

This chapter has sought to understand more about speculation by looking closely at one particular speculative activity in the foreign exchange market. Many of the characteristics of speculation that have already been identified are evident in the carry trade: there are real effects; there is some information that speculators take advantage of; there are feedback effects and momentum; and, there is complexity.

As we have seen in Section there are a broad range of cases where monetary authorities of investment currencies have struggled to contain exchange rates and inflationary forces when carry trade positions have been established. If the exchange rate is fixed, there is a need to purchase overseas assets, expanding the central bank balance sheet and the monetary base at a time when domestic banks are full of the deposits of carry trade investors. If the exchange rate is allowed to float, there is a loss of competitiveness or pressure to reduce domestic interest rates. In either case, the short-run impact on domestic demand is likely to be positive through lower import or funding costs; the long run consequences are likely to be a hollowing out of domestic industry or asset price inflation. The negative consequences of the imbalances that have developed are likely to be exposed as a result of the crash that happens when capital reverses: the exchange rate, interest rates and asset prices fall; import prices increase, reserves and the monetary base shrink.

This speculation is based on the widely documented evidence that UIP does not hold. It is not noise trading. It has been established that the carry 
trade will, on average, be successful. There are funds and individuals willing to try to take advantage of this apparent inefficiency. Aggressive investment funds with short-term horizons are continually searching for these sort of anomalies while regular households can also be seduced by slick sales talk backed by glossy examples of the savings to be made by overseas borrowing.

The activity is even more attractive if others are participating. The level of uncertainty over the future exchange rate movements is very high. However, this is inevitably reduced in currency peg, particularly if the monetary and political authorities are pledging to fight the sort of depreciation that is to be feared. For regular households, there is a feeling of safety in numbers and it would be foolish to miss out. For more sophisticated investors, the greatest returns are for those at the start of the trend. Price momentum helps to further reduce any doubts by ensuring initial success: the carry trade causes the investment currency to appreciate rather than depreciate and the central bank may be fighting to keep the exchange rate down.

However, the analysis of the carry trade that has been conducted here suggests that there are large, unconventional risks associated with the strategy. There is a complexity that is not captured by conventional measures of risk. There are big risks, they happen rarely and they are not easy to predict. In addition, if expectations about the future depend so much upon what others think, any equilibrium will be fragile. Small doubts can turn complacency into panic. For institutional investors, there is a need to get out ahead of everyone else, for households, the risk of personal loss is compounded by the sense of more general economic crisis.

It has been argued here that the carry trade is a micro version of a Minsky- 
Kalecki-Levy speculative accelerator model where speculative activity and subsequent reversal are self-reinforcing. Hedge financing that errs towards speculative financing can mean that increased investment will raise profits sufficiently to ensure that they are enough to cover all payments. These are good investments. However, there is a limit to how far this can be pushed. Diminishing returns from investment will set in, ensuring that the financing scheme becomes speculative and raising the prospect of crash-risk. With the carry trade, the trades themselves tend to negate the tendency of the funding currency to appreciate against the investment currency, increasing the attraction of the trade and raising the funds devoted to the activity. However, this will increase the risk if there is a reversal as traders will be wary of such a turn-around and will be ready to exit, adding to the pressure for a crash, when it occurs.

\section{References}

Bansal, R. and Dahlquist, M. (1999), 'The forward premium puzzle: different tales from developed and emerging economies', Journal of International Economics 51(1), 115 - 144.

Berglof, E. (2010), Recovery and reform, Transition report, EBRD.

Blison, J. (1981), 'The 'speculative efficiency' hypothesis', The Journal of Business 54(3), 435-451.

Brenner, M. and Galai, D. (1989), 'New financial instruments for hedging changes in volatility', Financial Analysts Journal 45(4), 61-65. 
Brown, M. and De Haas, R. (2010), 'Foreign currency lending in emerging europe: Bank-level evidence', EBRD Working Paper (122).

Brunnermeier, M., Nagel, S. and Pedersen, L. (2008), 'Carry trades and currency crashes', NBER Working Papers (14473).

Brunnermeier, M. and Pedersen, L. (2009), 'Market liquidity and funding liquidity', Review of Financial Studies 22(6), 2201 - 2238.

Chicago Board of Trade (2009), 'The vix white paper'. URL: http://www.cboe.com/micro/vix/vixwhite.pdf

Chinn, M. and Meredith, G. (2004), 'Monetary policy and long-horizon uncovered interest parity', IMF Staff Papers 51, 409 - 430.

Demeterfi, K., Derman, E., Kamal, M. and Zou, J. (1999), 'More than you ever wanted to know about volatility swaps', Goldman Sachs Quantitative Strategies Research Notes .

Diamond, R. V. (2012), 'Vix as a variance swap'.

URL: http://ssrn.com/abstract=2030292

Engel, C. (1996), 'The forward discount anomaly and the risk premium: A survey of recent evidence', Journal of Empirical Finance 3(2), 123 - 192.

Focus on European Economic Integration: Foreign Currency Loans (2011), Quarterly Focus Q1, Oesterreichische Natonal Bank.

Frankel, J. A. and Froot, K. (1990), 'Chartists, fundamentalists and trading in the foreign exchange market', The America Economic Review 80(2), 181 $-185$. 
Froot, K. (1990), 'Short rates and expected asset returns', NBER Working Paper (3247).

Froot, K. and Thaler, R. (1990), 'Anomolies: Foreign exchange', The Journal of Economic Perspectives 4(3), 179 - 192.

Gabrisch, H. and Orlowski, L. (2011), 'The extreme risk problem for monetary policies of the euro-candidates', Comparative Economic Studies $53,511-534$.

Habib, M. and Stracca, L. (2012), 'Getting beyond carry trade: What makes a safe haven currency?', Journal of International Economics 87(1), 50 64.

IMF (2009), 'Classification of exchange rate arrangements and monetary policy frameworks'.

URL: http://www.imf.org/external/NP/mfd/er/index.aspx

Jurek, J. (2007), 'Crash-neutral currency carry trades', AFA Atlanta Meetings Paper.

Kahneman, D. and Tversky, A. (1979), 'Prospect theory: An analysis of decision under risk', Econometrica 47(2), 263-291.

Keynes, J. M. (1936), The General Theory of Employment, Money and Interest, Macmillan.

Korinek, A. (2011), 'Hot money and serial financial crises', IMF Economic Review 59, $306-339$. 
Lewis, K. K. (2008), Peso problem, in S. N. Durlauf and L. E. Blume, eds, 'The New Palgrave Dictionary of Economics', Palgrave Macmillan, Basingstoke.

Muth, J. F. (1961), 'Rational expectations and the theory of price movements', Econometrica 29, 315 - 335 .

R Core Team (2013), R: A Language and Environment for Statistical Computing, R Foundation for Statistical Computing, Vienna, Austria.

URL: http://www.R-project.org

Rogoff, K. (1980), 'Tests of the martingale model for foreign exchange futures markets', Massachusetts Institute of Technology (Ph.D Dissertation).

Roll, R. and Yan, S. (2000), 'An explanation of the forward premium puzzle', European Financial Management 6(2), 121 - 148.

Silverman, B. (1986), Density Estimation, Chapman and Hall, London.

Spronk, R., Vershoor, W. F. and Zwinkels, R. C. (2013), 'Carry trade and foreign exchange rate puzzles', European Economic Review 60, 17-31.

Venables, W. N. and Ripley, B. (2002), Modern Applied Statistics with S, Springer, New York.

Welch, B. (1951), 'On the comparison of several mean values: An alternative approach', Biometrika 38, 330 - 336 .

White, J. S. (1961), 'Asymptotic expansions for the mean and variance of the serial correlation coefficient', Biometrika 48(1 and 2), $85-94$. 